\title{
Placental Passage of Humulone and Protopine in an Ex Vivo Human Perfusion System
}

\author{
received \\ April 30, 2021 \\ accepted after revision \\ July 28, 2021 \\ published online \\ September 16, 2021 \\ Bibliography \\ Planta Med 2021; 87: 1192-1205 \\ DOI $10.1055 / a-1578-3803$ \\ ISSN 0032-0943 \\ (c) 2021. The Author(s). \\ This is an open access article published by Thieme under the terms of the Creative \\ Commons Attribution-NonDerivative-NonCommercial-License, permitting copying \\ and reproduction so long as the original work is given appropriate credit. Contents \\ may not be used for commercial purposes, or adapted, remixed, transformed or \\ built upon. (https://creativecommons.org/licenses/by-nc-nd/4.0/) \\ Georg Thieme Verlag KG, Rüdigerstraße 14, \\ 70469 Stuttgart, Germany
}

\section{Retraction}

The authors have retracted this paper after they discovered that one of the compounds commercially obtained was in fact another substance. This unfortunate situation was beyond the control of the authors who regret any confusion that may have been caused by the published results. 